\title{
Multiple Faces of Science in Ethical Environmental Decision-Making
}

\author{
Herman F Greene*
}

\section{Abstract}

This essay concerns the multiple faces of science in ethical environmental decision-making. Environmental crises pose existential threats to human and non-human life. Science is essential to any meaningful response to these crises, but science as it is conventionally understood and practiced is not adequate to the task. Drawing on the work of Bruno Latour in his 2013 Gifford Lectures on "Facing Gaia: Six Lectures on the Political Theology of Nature,"1 I will critique this understanding and practice in relation to four faces of science - (i) capacity builder, (ii) informer and guide, (iii) philosophy, and (iv) institutionand propose reforms.

Keywords: Latour, Gaia, Science, Environment, Fukushima, Development, Anthropocene

We of the late-modern period, tend to think of science as a discipline that looks objectively at a world out there, in other words that there are human subjects, scientists, who examine external objects and phenomena characterized by facts and laws. A corollary to this is that science is not political because it is concerned with the discovery of factual truths about the world. We

* J D, D Min., President, Center for Ecozoic Societies, Chapel Hill, North Carolina, USA; hfgreenenc@gmail.com

1 Bruno Latour, "Facing Gaia: Six Lectures on the Political Theology of Nature."Gifford Lectures on Natural Religion. Edinburgh, Scotland, February 18-28, 2013.http://www.bruno-latour.fr/sites/default/ files/ downloads/GIFFORD-SIX-LECTURES_1.pdf (accessed December 15, 2013). 
also tend to think that all scientific truths are part of a larger truth-while science examines the world from multiple perspectives, each partial truth fits into the whole truth like a piece in a jigsaw puzzle, and in this way science leads us nearer and nearer to a comprehensive understanding of nature. And finally we tend to think that science provides factual knowledge of what is right in relation to the environment and clear instructions on right action. These premises, developed in the modern period as science yielded spectacular insights into nature, are no longer warranted and they hinder science in relation to ethical environmental decision-making.

I serve on the Environmental Satellite Cooperation Circle of the United Religions Initiative. One of our members, Rebecca Gonzalez-Tobias, is close to indigenous people in North America and elsewhere. While I care deeply about environmental issues, she lives them in an interior, passionate way more than I. Recently she brought Carol Wolman of Fukushima Response to one of the meetings of this cooperation circle. Wolman informed the circle of a threat to all of Earth related to the Fukushima nuclear plants. I wasn't at the meeting but when I heard of Wolman's report, it surprised me. Since the earthquake that damaged the plants occurred in March 2011, I thought everything was under control. To the contrary, there remain 1,400 fuel rods in a damaged pool at Fukushima 4 containing many times the radioactive cesium that was released in the bombing of Hiroshima. These rods would be at risk were another large earthquake to occur. Over six thousand rods sit in a common storage pool, which because of radiation at the site cannot be continuously cooled. So, in November 2013, a delicate operation began to remove the rods and move them to a safer storage facility. If the rods touch or are exposed there is a risk of an uncontrollable nuclear reaction and the release of large amounts of radiation. Because of the damaged condition of the plants, one person compared the operation of removing the 300 kilogram assemblies to removing cigarettes from a wet cigarette package. ${ }^{2}$

2 Harvey Wasserman. "Pandora's Atomic Box Score," November 10, 2013.http:/ / ecowatch.com/2013/11/10/pandoras-atomic-box-score/ 
In late September 2013, Indigenous Elders and Medicine People of North and South America united for four days in sacred ceremony in Green Grass, South Dakota, and out of that gathering came a "Council Statement." Gonzalez-Tobias worked with these leaders to have this statement presented at the Church Center for the United Nations on November 14, 2013. Chief Arvol Looking Horse, $19^{\text {th }}$ Generation Keeper of the White Buffalo Calf Bundle, Spiritual Leader of the Lakota, Dakota, Nakota Oyate Sioux made the presentation.

The Creator created the People of the Earth into the Land at the beginning of Creation and gave us a way of life. This way of life has been passed down generation-to-generation since the beginning. We have not honored this way of life through our own actions and we must live these original instructions in order to restore universal balance and harmony. We are a part of Creation; thus, if we break the Laws of Creation, we destroy ourselves [...].

We speak on behalf of all Creation today, to communicate an urgent message that man has gone too far, placing us in the state of survival. We warned that one day you would not be able to control what you have created. That day is here. Not heeding warnings from both Nature and the People of the Earth keeps us on the path of self destruction. This self-destructive path has led to the Fukushima nuclear crisis, Gulf oil spill, tar sands devastation, pipeline failures, impacts of carbon dioxide emissions and the destruction of ground water through hydraulic fracking, just to name a few. In addition, these activities and development continue to cause the deterioration and destruction of sacred places and sacred waters that are vital for life.

(accessed December 15, 2013); Charles Perrow. "Fukushima Forever." The Blog on Huffington Post, entry posted September 9, 2013, http://www.huffingtonpost.com/charles-perrow/fukushimaforever_b_3941589.html (accessed December 15, 2013. 
Powerful technologies are out of control and are threatening the future of all life. ${ }^{3}$

Reflecting on the role of science in relation to all of this, GonzalezTobias surprised me again when she said, "We don't need objective science anymore, we need science to go out and deal with these problems."

Intuitively I knew she was right, but I was still taken aback by what she said because, while I shared her concerns, I was trained to think of objective science as good science.

Bruno Latour in his 2013 Gifford Lectures on "Facing Gaia"made a similar point as Gonzalez-Tobias in regard to science, but in a different way. He argued that the objectivity of science today is a pretense, that science is highly politicized and reflects the viewpoints of various scientists. It is therefore up to scientists, indeed of all humanity, to accept the reality of the Anthropocene and get to work on living within Earth's means. To do so means to abandon the idea of Earth as limitless resource, and to accept that we are Earth bound - "Earthbound" he suggests is the new word for humans. (Latour, 3)

In his lectures, Latour, critiques the premises regarding the objectivity of science that I discussed above. While he acknowledges that science does discover objective truths about nature, it places these truths at risk by projecting them into the status of universality and not acknowledging that science is situated-situated in institutions, in viewpoints, in the formulation of problems and experiment, in the selection of data, and so on. Science that accepts it is situated, he believes, is better science (Latour, 87).

With regard to the ability of science to progressively build up a unity of truth, instead science gives us a bewildering array of disciplines, tests, results, causes and effects, and entangled feedback loops that are unable to be unified. Hence science finds itself in a "post-epistemological phase" where prevailing "truth" is decided through a political process (Latour, 131). Science no longer

3 Spiritual People of North and South America, "Council Statement." http:/ / caretakersofmotherearth.com/ (accessed December 15, 2013). 
acts as a neutral, third-party referee and the common world must be continuously composed by agreement (Latour, 8).

Latour calls attention to other premises that no longer hold. Here are just a few:

- We no longer live in history but in geostory, Earth understood not as a system but as a narrative in which we must locate ourselves. (p. 3)

- There is no environment anymore because humans are entangled in all of Earth. Hence we have no more need of environmentalism, we are post-natural. (p. 125)

- Rather than science being indisputable, almost every topic is a field of contention. (p. 19)

- Science is no longer the referee in complex matters such as climate change because of the multiple loops that have to be established. (p. 102)

- We have a development model that calls for modernizing Earth, but we cannot do so because we do not have five planets to live on, we have only one. (p. 126)

- The power of invention and surprise has shifted from humans to non-humans. Human institutions, laws, customs, even science, do not keep pace with the accelerating change of Earth. (p. 129)

The largest area where new understanding is needed concerns the former separation of humans and nature and the shift to the new dynamic mixing bowl of the Anthropocene. Earth, which has been the stage for human history, has now become the central player (Latour 3). Once indifferent to human affairs, Earth is now very sensitive to them (Latour, 96), and it imposes boundaries and conditions. To make clear that in the Anthropocene we are not dealing with Mother Earth anymore, for "Earth," Latour substitutes "Gaia" as presented by James Lovelock. Gaia is an organism, which is self-regulating and nurturing, but also one that may turn against us and kill us.

We have known about the potential for an eruption of Gaia for a few decades, but we have thought we should be concerned about 
this for the sake of future generations. Events have moved more quickly than we had imagined. Now the adverse changes we anticipated in a distant future may occur by 2020 or 2050, within the lifetimes of present generations. To live authentically in the Anthropocene is to embrace a secular form of eschatology, the sense that we are living at the end of time. We do this, not so that we may be carried away into an other-worldly realm, but that we may survive on Earth (Latour, 112).

Latour illustrates the difficulty science has in adapting to the Anthropocene by relating the story of how the question whether we have entered the Anthropocene epoch was dealt with at the $34^{\text {th }}$ International Geological Congress held in Brisbane, Australia, in 2012. At that Congress, the determining body, The SubCommission on Quaternary Stratigraphy, reported the issue was still under review and additional funding and study would be needed with the hope that consensus could be reached by 2016 (Latour, 75-76). Latour questioned this reticence given that human consumption of energy may soon approach the energy generated by plate tectonic forces; humans are the main agent in the production and distribution of the nitrogen cycle; and humans are complicit in the termination of species that may be the sixth mass extinction in the history of the planet (Latour, 76).

Taking effective action in the Anthropocene is difficult because the success of any one person depends on actions taken by many other people and entities. We labor under the domination of "The Economy." We are affected by our own fear and denial in facing the threats coming at us. We are caught in a welter of data and analysis. We don't have models for effective action sufficient to the challenge. Ecologists look forward for a practical vision of the future; modernists, Latour says, look backward. They revel in the escape from the bondage of the past and move to a Utopian future without realistic content (Latour, 106). The mistake made by many, let us call them ecologists, who have recognized the situation and have acted is that they have acted on the assumption there is some transcendent truth, moral obligation or spiritual attraction that will call forth global environmental responsibility. They invoke these transcendent powers with the hope of bypassing politics, but they cannot (Latour, 114). 
Challenging agricultural practices, limiting coal emissions, measuring declines in ice packs or the rise of sea levels, ecologists are puzzled that they encounter resistance. They call for reason and seek to prevail by improved data sets and arguments. The resistance, however, comes not because they are not reasonable, or objective, or because their data sets are not good, it comes because they are "changing every body's world" (Latour, 116).

Latour likens the situation to that of war. We have entered a new state of nature, a Hobbesian condition of a war of all against all, with the protagonists now including tuna, and sea levels and carbon emissions as well as the various human factions. This time though it is not a condition before people enter into a social contract, it is a present condition (Latour, 103). It is a world war"the Two Hundred Years World War" (Latour, 115).

Given this, Latour looks to an unlikely source for guidance: Carl Schmitt, a German political theorist who was a leader in the Nazi party during the time of Hitler, and whose work has had much influence on American Neoconservatives. In doing so, Latour embarks on the perilous advocacy of political theology and political ecology.

Schmitt's notion of the political begins with the definition of the enemy.

The political enemy need not be morally evil or aesthetically ugly; he need not appear as an economic competitor, and it may even be advantageous to engage with him in business transactions. But he is, nonetheless, the other, the stranger; and it is sufficient for his nature that he is, in a specially intense way, existentially something different and alien, so that in the extreme case conflicts with him are possible. These can neither be decided by a previously determined general norm nor by the judgment of a disinterested and therefore neutral third party. ${ }^{4}$

${ }^{4}$ Carl Schmitt Concept of the Political, expanded ed., trans. George Schwab. Chicago, IL: University of Chicago Press, 2007), 27, quoted in Latour, 105. 
Schmitt anticipates engagement with the enemy, while ecologists dream of a pacified Earth united by a State of Nature. Latour writes:

[This utopia] is still the horizon of those who hope to manage, engineer or re-engineer the planet; of those who wish to get by with 'sustainable development'; and of those who claim to be the good intendant, the earnest butler, the clever gardener or the careful steward of the Earth. In brief it is the dream of those who would prefer to do 'without politics' altogether.

The great virtue of dangerous and reactionary thinkers like Schmitt is to force us to make a choice much starker than that of so many wishy-washy ecologists still swayed by unremitting hope. Schmitt's choice is terribly clear: either you agree to tell foes from friends, and then you engage in politics, sharply defining the borderlines of real enough wars - 'wars about what the world is made of' —; or you shy away from waging wars and having enemies, but then you do away with politics.

Not being bellicose, Latour says he would prefer not waging wars and doing away with politics. But to take this common sense approach, he says, is criminal. Either our reliance on this common sense will do away with politics by vanquishing civilization, or politics will "resuscitate nature" (Latour, 105).

Within this context, he reluctantly but unflinchingly offers these observations on what is needed:

- Like Gonzalez-Tobias, he says we don't need objective science anymore; ecologists should be explicit about their war aims and who their friends and enemies are (Latour, 116).

- A political ecology is needed. For this to occur we need to accept that the human race is divided into collectivities in conflict with each other. (p. 116)

- A political theology of nature is needed. In this theology, we are not drawn by a transcendent God or even a transcendent Cult of Nature. Rather we are drawn to Gaia 
which commands and orders.5Our congregation is a political community. Our disciplines are natural history and biology. (p. 133) Holiness is to be solemnly and definitely bounded. (p. 136)

- We need to locate ourselves through geostory. We do this by cocooning ourselves in the loops and feedbacks of thermohaline circulation, carbon, hydro- and nitrogen cycles, deforestation and biodiversity loss, greenhouse gas emissions, ecological footprint, acidification of oceans, erosion, overgrazing, soil fertility, methane production, and climate change, so that "progressively, thread after thread, the knowledge of where we reside and on what we depend [...] can gain greater relevance and feel more urgent." (p. 95)

- In geostory every loop has to be narrated, lamented, and collectively ritualized. (p. 134)

- It is necessary to occupy a space or territory but this is not land in a geographical, national or bioregional or local sense, it is a series of other responsible agents necessary to survive in the long run. (p. 119)

- Non-humans must be recognized as actors in our associations. (p. 125) How strong their voices will be must be composed. There is no arbiter. (p. 137)

- Geostory must be brought together with geopolitics. The laws of the new polity have to be invented and be selfimposed. (p. 136)

- Plus ultra, always something more, is the maxim of the modernists, but for the Earthbound it is plus intra, inside

5 Regarding Gaia. Latour says the accumulation of loops of responses implies an agency, Gaia - "a power that does listen and answer," to which we must become responsible. To personify Gaia is not to imply an integrated person, but an entity like a nation that is "politically assembled." Latour, 135. 
Gaia, inside limits. The limits have to be decided from the inside of people, in the body politic. (p. 133)

- Science is connected to soil by instruments. (p. 120). By its monitoring and datasets it renders us sensible to Gaia. Science becomes the new aesthetics. Without science our sensibility dims and disappears. (p. 130)

- Yet art too has its place. While science is the primary collecting agent by which we become sensible to Gaia, future rites and rituals to hold us conscious to our new vocations is another story. This is for playwrights, curators and composers. (p. 142)

While not given as a conclusion by Latour, I found his statements about the social contract to serve as one. He said we should not be alarmed that the controversies arising as ecological concerns or from disturbance of planetary life will destroy the social contract, but rather that we have never yet conceived of a social contract that will hold together in the encounter with Gaia. (p. 104) Arriving at such a contract has to be assembled bit by bit. It has to be composed. The task of building the new Republic is a long way off. It has to be decided from within the people. "Without decision, there is no body politics, no liberty, [no] autonomy." (p. 133)

With this as background, let us look at four faces of science in ethical environmental decision-making: science as (1) capacity builder, (2) informer and guide, (3) philosophy, and (4) institution.

\section{First Face: Science as Capacity Builder}

The first face of science I will discuss is that of capacity builder. What role should science as capacity builder play in the future? Paul Raskin and his co-authors of Great Transition, ${ }^{6}$ being wellinformed on the environmental and other factors shaping the world, see three ways of thinking about the global future: Conventional Worlds, Barbarization, and Great Transition with two variants in each.

6 Paul Raskin, et al. Great Transition: The Promise and Lure of the Times Ahead. Boston, MA: Stockholm Environment Institute, 2002, 14-16. 
In Conventional Worlds, the future proceeds without major interruptions. Some focus on Market Forces as driving world development, and others focus on Policy Reform to address issues such as poverty and environmental issues. This is business as usual with ongoing improvements. It is the scenario out of which business and governments operate as, to some extent, do each of us in our daily lives and in our places of work.

Barbarization anticipates that Conventional Worlds will not be able to manage the problems of the future. Economic and social institutions are disrupted leading either to Breakdown and conflict and crisis or Fortress World where authoritarian control and defensive measures are applied to establish security.

In the Great Transition scenario there is also a movement away from Conventional Worlds, but in the direction of a positive transformation. There are two variants, Eco-Communalism and New Sustainability Paradigm. Eco-Communalism focuses on localism, bioregionalism, participatory democracy, organic agriculture, crafts and autarky. In the New Sustainability Paradigm, the complexity and globalism of Conventional Worlds continues but the character of civilization is changed by new values and there is a greater role for civil society. The authors of the Great Transition favor the New Sustainability Paradigm and do not see Eco-Communalism on a large scale without first passing through some form of Barbarization. ${ }^{7}$

Elements of the New Sustainability Paradigm are given in numerous documents. Moving into this paradigm requires transforming energy production to make energy available in greater quantities and on a wider scale and yet without greenhouse gas emissions. It also requires a new transportation system and redesign of cities, suburbs and even rural areas. It requires greatly increased resource efficiency and greatly reduced toxicity. Goods need to be more durable, repairable and recyclable. Other species need protection and in a way that augments and is coherent with the functioning of natural systems. Further, this paradigm calls for

${ }^{7}$ Great Transition, 15 
increased social equity and reduced conflict and operating within planetary boundaries.

The New Sustainability Paradigm has an appeal because it preserves the benefits of modernity while extending them to more people and by definition it operates within planetary boundaries. It has a Utopian aspect to it, however, and, like sustainable development, it is relatively easy for a broad range of people to be for it without any real agreement on what it means.

Personally I think we should strive for the New Sustainability Paradigm, but only if we take some of the Utopianism out of it and come to agreement on parameters. For example, living within planetary boundaries must mean that we actually do so with the technology that we have and reasonably expect we can develop and not with fantastic technology we speculate will be developed. Further, the paradigm should not assume that the relatively wealthy will maintain present lifestyles with a miraculous reduction of ecological footprint. The paradigm must provide for sustainable sufficiency for all people and for protection of biodiversity and natural systems. The paradigm should not be seen as being in competition with Eco-Communalism because resilient, relatively self-sufficient local communities will be needed.

Achieving the Great Transition will not be easy. It will not happen without taking into account Latour's realism about the Anthropocene. Science will have a critical role to play. We are far from knowing, for example, how to produce abundant energy for all without harmful emissions. Further, if we are to achieve a standard of living for all humans like that of the middle-class in advanced industrial nations, we will have to find those missing four planets in this planet and not by exploiting this planet four times as fast.

Not just any science, however, is needed. For the New Sustainability Paradigm, some science is enemy and some is friend. As I shall discuss in the science as institution section of this paper, at present most of science is for Conventional Worlds or Barbarization. 


\section{Second Face: Science as Informer and Guide}

The second face of science in ethical environmental decisionmaking is that of informer and guide. With regard to informer, Latour makes a powerful statement that when dealing with Gaia everything depends on our monitoring instruments and analyses. He says when we have instruments our sensibility increases and when we don't it dims. This is where he introduces the idea of science being in the Anthropocene the new aesthetics, that which makes us sensitively aware. (p. 130)

He makes a somewhat contrary observation however when he attends to the deluge of scientific information that we receive, information that may be contradictory and is almost always incomplete. So rather than science providing clear, objective information, what science provides is a jumble of intertwined interpretations. Reigning interpretations emerge not as unified, widely held and established truths, but more in the way legal precedents are developed through a long winding process and many court cases. They are never final - the precedents reign only so long as they continue to receive attention and are commented upon. (p. 130)

Further, as Latour points out, science emerges out of institutional, political and personal interests. This is exceedingly clear in the field of climate science and it is true in other fields as well. Consider pharmaceutical research. Here the science indeed resembles that of a legal process as scientists for pharmaceutical companies marshal evidence to support a drug and other scientists for regulatory agencies, NGOs or competitors marshal contrary evidence. A newspaper or magazine strives to provide scientific information of interest to its readers to sell copies. A journal prints peer-reviewed articles that reflect the politics in a field of study, politics that bear on funding of research and the prestige of authors and university departments.

The standard critique of this returns to a notion Latour rejects, which is there is a pure science out there and that ethical science should be done in a disinterested, dispassionate, and objective without regard to conflicting influences of politics, prestige, group affiliation and money. Latour will not, however, rescue scientists 
from the dilemma of living in a world of contested, imperfect information or the people they inform from having to decide and act based on such information.

Latour admonishes scientists not to hide behind the objectivity of Knowledge with a capital "K," but he is not saying for scientists to do bad science. Rather he is calling scientists to identify their interests and who are their friends and enemies. He is especially calling those who will accept the context of living in a world of planetary transformation to stand their ground and argue, with their allies, in the marketplace of ideas to establish their case. By speaking of a post-epistemological period, Latour is saying that scientists are advocates - they cannot appeal to an uncontested truth and remain above the fray. Every "truth" will be contested, indeed that is already the case.

And for those who would be informed by science, they must become scientifically literate to a degree and they too must enter into the fray of determining their truths based on imperfect, contested knowledge. To not do so is to lack sensibility to Gaia. One also has to name enemies on the side of being informed by science. On school boards and boards of universities around the world, the kind of science information students will receive is being contested, so too on the editorial and production boards of the various media.

When we consider science as guide in a world of planetary transformation, this raises many other issues. In the standard view, science doesn't draw conclusions, at least not until the evidence is overwhelming, it only informs. Further the view is that science does not have a stake in the implications or outcomes of the information being provided, nor do scientists have a social obligation to act on the information they provide. For Latour the standard view on science as guide is morally wrong.

In an article published in Nature Climate Change, climate scientists Kevin Anderson and Alice Bows took a position that I take to be fully aligned with Latour's view. Anderson and Bows argue there is no way that humanity can meet the target of keeping global warning below $2^{\circ} \mathrm{C}$ and stay within orthodox political and economic constraints. They write 
Scientists often assume that the most effective way of engaging is by presenting evidence, without daring to venture, at least explicitly, broader academic judgment[...] particularly when such judgment raises fundamental questions about the viability of so-called real world economics[...]. We [scientists] need to be less afraid of making academic judgments. Not unsubstantiated opinions and prejudice, but applying a mix of academic rigour, courage and humility to bring new and interdisciplinary insights into the emerging era [...]. Ultimately decisions on how to respond to climate change are the product of many constituencies contributing to the debate. Science is important among these and needs to be communicated clearly, honestly and without fear. ${ }^{8}$

Anderson and Bows made these comments out of convictions that economic growth is incompatible with keeping global warming within acceptable ranges and that few scientists disagree with this, though they couch this at the microphone and in publications. This is what they find unacceptable and dangerous.

If science is to be a guide in environmental decision-making, it must make judgments and enter the fray.

\section{Third Face: Science as Philosophy}

The third face of science is that of philosophy. Most scientists probably don't think of science as philosophy or that they are practicing or teaching a philosophy. Yet as any student of religion or philosophy knows, issues concerning science and religion or philosophy have been paramount throughout the modern period.

Science has been so successful in explaining nature that the subject matter and method of its study have come to be understood as descriptive of existence (ontology) and the results of its findings as explanatory of the universe (cosmology). Prior to the modern period scientific questions were addressed through natural

8 Kevin Anderson and Alice Bows. "A New Paradigm for Climate Change." Nature Climate Change, 2 (2012): 639-640. 
philosophy and cosmology, both of which were branches of metaphysics. Beginning in the $18^{\text {th }}$ century science, as a body of knowledge based on empirical observation and experiment, was separated from philosophy, and cosmology came to be understood primarily as physical cosmology rather than metaphysical cosmology.

While not fully realized, there has been a movement to explain everything from atoms, to stars, to geology, to biology, to the humanities by the limited causal categories of science. That we have not yet been able to explain everything based on these categories, people of this persuasion say, is because we have not yet gone far enough. In contrast to the old philosophical and religious cosmologies, which saw meaning and purpose in the universe, materialistic science espouses a universe having neither. This antiphilosophical message of science is itself a philosophy. We do not know how far it has penetrated until we hear our neighbor say, "I am happy because I have exercised and exercise releases favorable chemicals in my body." We are, and all of nature is, as it were, physics and chemistry.

Rupert Sheldrake in Science Set Free states these core beliefs of materialistic science:

1. Everything is essentially mechanical.

2. All matter is unconscious.

3. The total amount of matter and energy is always the same.

4. The laws of nature are fixed.

5. Nature is purposeless, and evolution has no goal or direction.

6. All biological inheritance is material carried in genetic and other material structures.

7. Minds and brains are one and the same.

8. Memories are stored as material traces and are wiped out at death.

9. Unexplained phenomenon, such as telepathy, are illusory.

10. Mechanistic medicine is the only kind that works. ${ }^{9}$

9 Rupert Sheldrake. Science Set Free. New York: Deepak Chopra Books, 2012, 7-8. 
Physicist Stephen Hawking and his co-author Stephen Mlodinow in The Grand Design confirm, without qualification, these core beliefs by proclaiming that philosophy is dead because it has not kept up with science. Later they state that scientific determinism, the idea that "given the state of the universe at one time, a complete set of laws fully determines both the future and the past," is the basis of all modern science. ${ }^{10}$ On the nature of biological processes and free will they state:

Though we feel that we can choose what we do, our understanding of the molecular basis of biology shows that biological processes are governed by the laws of physics and chemistry and therefore are as determined as the orbits of the planets. Recent experiments in neuroscience support the view that it is our physical brain, following the known laws of science that determines our actions, and not some agency that exists outside those laws. [...]. It is hard to imagine how free will can operate if our behavior is determined by physical law, so it seems that we are no more than biological machines and that free will is just an illusion. ${ }^{11}$

Thus, they explain away the very activity that is presupposed in their book writing, that they are engaged in a creative, intentional, decision-making activity. In addition, they explain away the cognitive, affective, decisional, moral and purposive activities that are required for humans to take up the challenge of facing Gaia in a time of global transformation. Such observations are not neutral; they have their effect on the conduct of science and also on conduct of life by all people. This anti-philosophy philosophy removes moral culpability and responsibility and meaning and purpose as categorial features of the world.

Such philosophy is not, however, required by science. Accepting materialism and determinism for the purposes of scientific investigation of limited domains of experience is one thing, to offer them as complete explanations of life, being and the universe in

10 Stephen Hawking and Leonard Mlodinow. The Grand Design, Kindle, ed. New York: Random House Publishing Group, 2010, 289-90.

11 Stephen Hawking and Leonard Mlodinow. The Grand Design, 308-313. 
their totality is another. It is the latter that is the problem. There is still that which goes beyond physics, meta-physics, there is still religion, philosophy and the humanities, and biological processes, evolution and consciousness that cannot be explained by materialism and determinism, not because the science is incomplete but because these categories of explanation are incomplete.

Though the problems raised by the application of materialism and determinism outside the limited domains of experience examined by science are important, Rupert Sheldrake argues that they are also damaging to science itself. They make science dogmatic and constrict it. Fields of inquiry are denied and with it knowledge is lost. It is commonly thought that science determines the categorial features of the world by empirical observation. E. Maynard Adams argued against this saying "The way we empirically investigate and think about any subject matter presupposes commitments about its categorial features and structures. These presuppositions govern the outcome of empirical investigations rather than being the products of such investigations." 12

Science contributes to our understanding of the nature of existence and of the universe, but it is not an ontology or a cosmology in the philosophical sense. Thomas Berry said "When the science believes it is a cosmology, it is a danger, but when it functions within an adequate cosmology it becomes a wisdom. "He could have said the same about when science believes it is an ontology.

The cover flap review of Bruno Latour's most recent book, An Inquiry into Modes of Existence, states:

Though scientific knowledge corresponds to only one of the many possible modes of existence [...], an unrealistic vision of science has become the arbiter or reality and truth, seducing us into judging all values by a single standard. Latour implores us to recover other modes of existence in

12 E Maynard Adams, "The Mission of Philosophy Today," Metaphilosophy 31, no. 4 (July 2000): 356. 
order to do justice to the plurality of truth conditions that Moderns have discovered throughout their history. ${ }^{13}$

In addition, to giving up the idea that there is a unified objective scientific truth, science must give up the imperial position as the standard for all knowledge. Further, what is needed now is a science of life, rather than an attempt to conform life to deterministic materialism. The overarching concern of our historical period is the ecological crisis, the need to provide for a viable human future within planetary boundaries. This is what Latour means when he speaks of the Anthropocene as the overarching context. This is what Thomas Berry meats when he described the Great Work of our time as moving on from a terminal Cenozoic to an Ecozoic era in the history of planet Earth. ${ }^{14}$

Science needs to become conscious of its unexamined presuppositions, presuppositions that are more in tune with a prior period of Newtonian mechanistic science. Science is not philosophy. Science has philosophical implications, but there needs to be a continuing reexamination of the categorial features and structures of existence that are implicit in science at any given time and how they need to be reformed so that science may be effective. For science to be the needed wisdom in this time of planetary transformation, it needs to operate out of an integral, animate, political philosophy. ${ }^{15}$ I use the term "political" here to capture Latour's insight that we live in a post-epistemological period and that guiding truths must be established in public discourse including multiple modes of experience.

${ }^{13}$ Cover flap review of Bruno Latour.An Inquiry into Modes of Existence: An Anthropology of the Moderns, trans. Catherine Porter. Cambridge, MA: Harvard University Press, 2013).

${ }^{14}$ See generally, Thomas Berry. The Great Work. New York: Bell Tower, 1999.

15 Process philosophies, especially those based on the work of Alfred North Whitehead, may be particularly fruitful in examining and rethinking the presuppositions of science. 


\section{Fourth Face: Science as Institution}

The fourth face of science I will discuss is that of institution. Science is a big business amounting to about $1.7 \%$ of world GDP and approximately $\$ 1.6$ trillion $^{16}$ in annual spending. Since the beginning of the $21^{\text {st }}$ century, global annual spending on research and development has nearly doubled. There are over seven million research scientists and 1.6 million science publications. ${ }^{17}$ The United States leads in spending at about $\$ 465$ billion per year, ${ }^{18}$ but Israel, at $4.3 \%$, leads in percentage of GDP devoted to research and development. ${ }^{19}$

In the United States, in 1965 more than $60 \%$ of research and development was funded by the federal government, 20 whereas private industry now provides $65 \%$ of the funding. ${ }^{21}$ Academia, in the United States, performs $60 \%$ of basic research and total spending on research and development in academia is now in excess of $\$ 60$ billion a year with most of the funding for academic research coming from the federal government. ${ }^{22}$ About $55 \%$ of all US government-funded research is for defense. ${ }^{23}$ During the 2013

16 Battelle Memorial Institute and Research and Development Magazine, 2014 Global Research and Development Forecast (2013), 16, http://www.battelle.org/docs/tpp/2014_global_rd_funding_forecast.pdf (accessed December 25, 2013).

17 The Royal Society. Knowledge, Networks and Nations: Global Scientific Collaboration in the 21st Century. London: The Royal Society, 2011, 16, http://royalsociety.org/uploadedFiles/Royal_Society_Content/Influenci ng_Policy/Reports/2011-03-28-Knowledge-networks-nations.pdf

(accessed December 23, 2013).

18 Battelle, 1.

${ }^{19}$ Battelle, 7 .

20 Jennifer Washburn, "Science's Worst Enemy: Corporate Funding," Discover (October 11, 2007), http://discovermagazine.com/2007/ oct/ sciences-worst-enemy-private-funding\#.UrgcmfRDvNlaccessed

December 23, 2013).

${ }^{21}$ Battelle, 8 .

${ }^{22}$ Battelle 1.

${ }^{23}$ Binyamin Appelbaum, "A Shrinking Military Budget May Take Neighbors With It," New York Times (January 6, 2012), http:/ / www.nytimes.com/2012/01/07/us/a-hidden-cost-of-military- 
fiscal year, the US Defense Department spent over $\$ 80$ billion on research and development, an amount that exceeded the defense spending, not just for research but for all purposes, of all countries in the world except China and Russia. ${ }^{24}$ This does not even take into account large expenditures for research and development by the US Department for Homeland Security.

Insanely we arm ourselves as individuals and states to make us "safe." Yet this does nothing to protect us against the environmental ruin we face. In 2013 the budget for the United States Defense Department was nearly $\$ 690$ billion, ${ }^{25}$ for the US Department of Homeland Security it was $\$ 60$ billion $^{26}$ for the Environmental Protection Agency it was $\$ 8.3$ billion, barely 1\% of the budget for defense and homeland security. ${ }^{27}$ The US federal government spent $\$ 4.36$ billion on non-defense energy research in 2012 , about $3.6 \%$ of total federally funded research, a significant portion of which was for high efficiency coal, carbon capture and storage and nuclear energy. Non-defense energy research will significantly decline going forward as stimulus spending ends and

cuts-could-be-invention-and-its-

industries.html?_r=3\&nl=todaysheadlines\&emc=tha23\&pagewanted=all\& \&pagewanted=print (accessed December 18, 2013).

24 See data from Stockholm International Peace Research Institute, SIPRI Yearbook 2013: Armaments, Disarmament and International Security, presented in Wikipedia contributors, "List of countries by military expenditures," Wikipedia, The Free Encyclopedia, http://en.wikipedia.org/ w/index.php?title=List_of_countries_by_military_expenditures\&oldid=5 86559166 (accessed December 18, 2013).

${ }^{25}$ Center on Budget and Policy Priorities, "Policy Basics: Where Do Our Federal Tax Dollars Go?" (April 12, 2013), http://www.cbpp.org/cms/ ?fa $=$ view\&id=1258 (accessed December 18, 2013).

26Department of Homeland Security, FY 2013 Budget in Brief, http://www.dhs.gov/xlibrary/assets/mgmt/dhs-budget-in-brieffy2013.pdf (accessed December 18, 2013).

27 United States Environmental Protection Agency, Office of the Chief Financial Officer, FY 2013 EPA Budget in Brief (Publication Number: EPA190-S-12-001, February 2012), http://yosemite.epa.gov/ sab\%5CSABPRODUCT.NSF/

2B686066C751F34A852579A4007023C2/\$File/FY2013_BIB.pdf (accessed December 18, 2013). 
Congressional budget cuts take effect. ${ }^{28}$ Even at the 2012 levels, the research and development expenditures for alternative energy was significantly less than the International Energy Agency says is required to keep global warming below $2^{\circ} \mathrm{C} .{ }^{29}$

Performance of scientific research generally follows the funding for research and competition for that funding is intense. Academic researchers are expected to obtain extramural funding for their research, including money for their own salaries. They spend countless hours writing grants to obtain such grants. Those who work for industry as employees or as contractors are under pressure to produce commercial results. Whether the work is funded by government or private industry, it is obtained in a highly political atmosphere in which the underlying tenets of neoliberal, market, growth-based, globalized economics prevail and exert a dominant influence. Scientists struggle to build and maintain their reputations and their networks and coalitions to support their kind of science. The cost of science rises, and scientists are dependent on institutional support for their work.

The Economist, in a recent article on "Trouble at the Lab," 30 described some of the outcomes of this situation. Scientists seek to make breakthrough discoveries and science publications like to publish them to interest their readers. Data may be manipulated to produce what seem to be promising results. Only a little over one in ten papers published document negative results. Studies confirming prior published results are regarded as old news and are poorly funded and less likely to be published. The article reports, "Amgen, an American drug company, tried to replicate 53

28 Brad Plumer, "Four Charts that Show the U.S. Spends Too Little on Energy Research," Washington Post (April 98, 2013), http://www.washingtonpost.com/blogs/wonkblog/wp/2013/04/09/th ree-charts-that-show-the-u-s-spends-too-little-on-energyresearch/ (accessed December 23, 2013).

29 See generally, IEA Report for the Clean Energy Ministerial, Global Gaps in Clean Energy RDED: Update and Recommendations for International Collaboration (Paris: International Energy Agency, 2010), http://www.iea.org/publications/freepublications/publication/global_g aps.pdf (accessed December 23, 2013).

30"Trouble at the Lab," The Economist, October 9, 2013. 
studies that they considered landmarks in the basic science of cancer, often cooperating closely with the original researchers to ensure that their experimental technique match the one used the first time around. [They] were only able to reproduce six." Another pattern all too common is the withholding of data from sponsored research that does not support the goals of the sponsor, ${ }^{31}$ or the publication of research that is deliberately skewed to support a sponsor's goals. ${ }^{32}$

This state of affairs is barely sufficient for, and reflects the ethos of, Conventional Worlds scenarios; it contributes to the Barbarization scenarios and is insufficient for the New Sustainability Paradigm. It is consistent with Latour's observation that science is highly politicized, in that it is dependent for funding on entities operating out of conventional economics and politics. Courageous scientists step out of convention to challenge the status quo, 33 but most are carried by the prevailing tide. Science cannot play the role it needs to play in ethical environmental decision-making without institutional reform.

\section{Conclusion}

In conclusion, we are at a critical point in history, not just human history but the history of our planet. The actions we take now will affect all of life for generations to come. Ecological catastrophes we once thought distant are present realities. We cannot avoid all of the consequences of past actions, nor can we bring about the changes to realize the New Sustainability Paradigm and return the planet to a normal state in a few years. This is a 200 year task and probably longer. Knowing this does not, however, remove the fierce urgency of acting now.

\footnotetext{
31 Washburn, 3.

32 See generally, Naomi Oreskes and Erik Conway, Merchants of Doubt: How a Handful of Scientists Obscured the Truth on Issues from Tobacco Smoke to Global Warming (New York: Bloomsbury Press, 2010).

33 See Naomi Klein, "How Science is Telling Us All to Revolt, New Statesman, October 29, 2013, http://www.newstatesman.com/2013/ 10/ science-says-revolt (accessed December 25, 2013).
} 
Latour brings a needed realism to effective action and he highlights the importance of science while calling for dramatic change in it. He re-designates Earth as Gaia to give it a personal dimension so that it and other non-human entities can be understood as prominent actors in our networks, and also to hold before us both its benefactor and destroyer aspects. Gaia's role in our human drama can no longer be taken for granted.

Latour highlights the importance of science when he observes that we cannot even be sensitive to Gaia without science and all of its monitoring instruments and analyses. It is the new aesthetic. Then he puts science in a post-epistemological, post-natural setting and the overarching context of the Anthropocene. He proposes a political ecology which requires that science understand it is part of a public political discourse and prevailing understandings will not emerge because they are, capital " $\mathrm{O}$," " $\mathrm{U}$ " and " $\mathrm{T}$," Objective Unified (and therefore unifying) Truth.

Following Carl Schmitt, Latour says that politics begins with identifying friends and enemies and recognizing that the human race is divided into collectivities in conflict with each other. We have entered a new Hobbesian condition of a war of all against all. There is a battle to be won to establish a new social contract that will hold in the encounter with Gaia.

In the Anthropocene he says we shouldn't worry about anthropomorphism. ${ }^{34}$ Further we should not worry about the environment because there isn't any. While it is somewhat frightening to say, the future will not be decided by appeals to a natural order, the rights of nature, biocentrism, or, for that matter, the market or the American dream. The future will be what we decide for it to be in a political contest with each other and with Gaia. Ours is not a time to be polite. This is the Two Hundred Years World War and that changes everything. It most certainly changes the role of science in ethical environmental decision-making.

${ }^{34}$ Latour, 74. 